\title{
Türk hukukunda mal için meşru müdafaa (1)
}

\section{Yazan: Asistan Jale GURAL}

\section{Giris :}

Haksız bir taarruza maruz kalan kimsenin; kanun himayesine müracaat mümkün olmayan hallerde gerek kendisinin ve gerekse baskasinm hayatını, canını, Irzını, kuvvetle bizzat müdafaa etmesi; medeniyetin bütün devirlerinde insanlara tanınmıs bir haktı. Tehlike kanun tanımaz

(1) Vidal - Magnol Cours de droit criminel et de science pénitentiaire: 1935; Code pénal annoté: E. Garçon 1901 - 1911; Traité de droit pénal Allemand: Fransızca tercümesi, Von Lists: $t, 1911$ - 1913; Traité élementaire de droit criminel et de législations penals comparées. H. Donnedieu 1943; Traité de dorit pénal français: Garraud, 1935; Précis élemantaire de droit pênal Garraud 1937); Commentaire de code pénal Suisse: Logos, 1939; Esquis de droit criminel Anglaise: Kenny, 1921 (Fransızca tercümesi); Outline of criminal law; Kenny, 1942; The book of English law Jenks 1943; History of English law befor the time of Edward: Sir F. Bollock and Matland, 1923; Pollok's law of torts: P. A. Landon 1939; Ceza kanunu şerhi (Turk ve ttalyan); Ceza hukuku: T. Taner; Les droit réels dans le C. CS: Wieland; Partie generals du code federal des obligation: V. Tuhr 1933; Le code civil suisse: Tuor 1942; Commentaire du code federal des obligations: A. Schneider et H. Fick; Borçlar kanunu şerhi: Türkçe tercümesi Funk; Borçlar kanunu şerhi: Türkçe tercümesi Curti Forer; Türk kanun medenisi şerhi: M. R. Belgesay, 1930; Borçlar hukuku: E. Arsebïk, 1943; Ayni haklar: Talebe notu, HC. Ǒ̌uzoğlu, 1941; Légitime défense en cas de possession et de détention: Parish, Revue pénitentiaire et de droit pénal, 1921, no, 6-7; Zilyetliğin gaspı ve ona karşı tecavïzden doğan tazminat ve ecri misil talepleri : Hirş: Medeni kanunun XV inci yıl dönümü; Meşru müdafảssmin genişliği ve mala karşı yapılan tecavüzlerden doğan müdafaa hakkı: T. Taner, Armağan 1944; M. Tan: Alman hukukunda meşru müdafaa, ad. cer. 1939; F. Erem: Türk hukukunda mal için meşru müdafaa., ad. cer. 1943, sayı 8 ; Gözübùyiuk: Modern ceza hukukunda mal için meşru müđafaa ad. cer. 1942. say., 5; H. Oner: Medeni ve ceza kanunun meşru müdafaaya dair hükiłmleri arasında mukayese: ad. cer. 1939; sayı 9; A. Atrus: Zilyetlik: Is haro mermuasi 1943, sayı 6; 
prensibinden cikmış olan bu hak (1) bütün ceza kanunları tarafindan bir beraet sebebi olarak telâkki edilmekle beraber muhtevası ve şümulü eskidenberi doktrin ve tatbikatta bir münakaşa konusu tesklil etmekte devam etmisti. Acaba ne gibi haklara karşı yapılan taarruzların kuvvetle def'i messrudur? Bu haklar meyanma mülkiyet hakkı da girer mi? Hukukçularin ısmarla üzerinde durdukları meselelerden biri de mülkiyete vâki tecavüzs karşı kuvvete müracaat etmenin hakl olup olmadığıdır. Bu mesele tïrlii içtihat ve telâkkilere yol açmış olduğu gibi, bumların tesirinde kalan kanun vazllarınca da türlü türlü hükümlerin konmasina sebebiyet verms.ir. Bizim hukuk sistemimiz acaba mal inin meşu müdafaayı kabul eder mi? Úzerinde durmak istediğimiz konunun esası işte budur.

Türk hukukunda meşru müdafaa umumî olarak C.K. $49 / 2$ nci maddesiyle kabul edilmistir. Bu madde meşru müdafaayı; yalnı şahısların gerek kendi ve gerekse başkalarinın, nef sine veya rrz:na karş vâki tecavüzlere hasretmis ve Ceza Kanunu mal için meşru müdafaayı istisnaen yalnız sahislara karșl şiddet kullanmak suretiyle yapılan tecavüzler için öngörmüstür. Diğer taraftan M.K. 894. bazı sartlar dairesinde zilyede, zilyetliğinin tecavüze uğraması halinde yedini zor kullanarak müdafaa hakkı tanımıs, B.K. 52 de bu müdafaanın borclar hukuku bakımından neticelerini tesbit etmiștir.

Mesru miklafaanm mahiyeti hakkmdaki nazariyeler :

Taarruza mâruz kalan şahıs, bu tecaviuzleri suc sayılan mukabil fiillerle defetmesine rağmen nasıl oluyor da kendisine bir cezâ̂ mesuliyet atfedilmiyor? Bu sorunun cevabını meşu müdafaanm mahiyetini izah eden nazariyeier vermektedir. Ayni zamanda meşru müdafaamın; geçirmiş olduğu tekâmül safhalarını da gösteren bu muhtelif görüş tarzlarmı ikj kısımda toplamak mümkündür:

I - Sübjektif nazariye'er: Meşru müdafaayı yalnız bir muafiyet sebebi olarak telákki ederler:

a - Meșrî müdafaa, manevî cebir esnasma yani failin akıl haletinin teşevvüșe uğramasına dayanır (2). Șahıs bu suretle yalnız kendini müdafaa insiyakina uyarak hareket eder (3).

Fakat bu göıüs tarzı ile, bașkalarına karşı yapılmıs bir taarruz için kuvvete müracaatın neden meşrû olduğu izah edilemez.

(1) H. Tan: Sa: 289.

(2) Tahrir : Sa: 379

(3) Gorratura: Sa: 11 
b - Tecaviiz; nasil bir haksızlık ise şahsî müdafaa da öyle bir haksızlık teșil eder. Tecavüz edenlere yalnız Devlet ceza verebilir. Bununla beraber müdafa yolunda böyle bir fiil işleyen cezalandırlmaz. Çünkü müdafa ile tecavüz arasında bir takas vâki olmuştur.

Bu nazariye de meşrû müdafaanin mahiyetini izah etmez, buna göre müdafaanın cezayı müstelzim olmaması için müdafaa ile tecavüz arasinda bir muadelet bulunması icabedecekti (1), halbuki hiç bir kanun müdafaayı cezasız bırakmak için böyle tam bir müsavat aramaz.

II - Objektif nazariyeler : Bu nazariyeler müdafaayı bir hak ve bir beraat sebebi olarak telâkki ederler (2) :

a - Haksızlığın butlanı nazariyesi (3) : Hegel'e göre haksız tecavïz başkasının hakkını inkâr demektir, müdafa ise bu inkârı ortadan kaldırarak yeniden hakkm teessüsünü temin ettiğinden bir hak hattâ bazan da bir vazifedir. Ihering hukuk için mücadele adlı kitabında da aymi fikri müdafaa etmektedir.

b - Meşru müdafaanın esası; , cemiyetin cezalandırmak hakkının muvakkaten ortadan kalkmıs olmasıdır. Cemiyet; haksız bir tecavüze karşı koymayı ancak bu tecavüzü zararsız bir hale sokabildiği ve herkesin hakkını müdafaa edebildiği müddetçe menedebilir. Karrera ve Wolf tarafından müdafaa edilmiş olan bu görüs tarz içtimai mukavele nazariyesine dayanir (4),

\section{c - Pozitif görüș:}

Meşru müdafaanın mahiytini en iyi ve doğru bir surette izah eden denilebilir ki bu son nazariyedir. Ferri tarafından ileri sürülmüs olan fikre göre; "haksız yere başkasınin hakkma tecavüz eden kimsenin bu hareketi; onun suç temayülünü ispat ettiğinden, meşru müdafaa suretiyle mutaarrizı zararsız bir hale getiren veya yok eden kimse, cemiyete muzir olanlarm cemiyetten uzaklasstırılması kaidesine uygun hareket etmistir 5). O bu hareketiyle yalnız kendini değil, ayni zamanda cemiyetin nizammı da korumuş ve ona faideli olmuștur. Çünkü cemiyetin namuslu bir adamin selâmetinde ve fena bir adamin ortadan kalkmasinda menfaati vardır. Bu suretle haksız tecavüze karşı koyan şahıs, hukuki, içtimai saiklere dayanmaktadır. Hareketinin mesruiyeti de buradan gelir,,,

(1) Tahrir : Sa. 379; Magnol: Sa. 312.

(2) tbid

(3) Mognol; S. 313.

(4) F. Erem : $\mathrm{Sa}: 606$.

(5) S. g.e: Sa: 607 
Şahsı müdafaa; içtimai kuvvet (âmme kuvveti) ile cemiyet içindeki intizamın ve asayişin devamı bakımından; aynı gayeyi hazdir. Zaten tecrübeler de göstermiștir ki suçuları müstakbel ceza korkusundan ziyade tecavüz etmek istedikleri kimsenin mukavemeti suc ișlemekten alakoymaktadır (1).

Hakkını meșru surette müdafaa eden kimseyi cezalandırmak; cezadan beklenen faideleri sağlamaz, zaten böyle bir kimseyi cezalandırmak ceza değil isskence olurdu (2).

Netice olarak diyebiliriz ki kendisinin veya bir başkasının hukukan himaye edilmiş bir varlığına (bien juridique) karşi yapılmıs bir tecavüzü; cemiyet kuvvetlerinin müdafaa etmesine muvakkaten imkân olmayam hallerde; kuvvetle defetmek meşrudur; hattâ bu bazan bir hak ve cemiyete karsı bir vazifedir.

\section{Meşru miidafaanın sartlari :}

Pozitivistler tarafından bir hak ve hattâ bazan bir vazife olarak kabul edilmiş olan meşru müdafaanın istimal şartlar ve sunırları nelerdir? Başka bir deyimle hukukan nasil tanzim edilmiştir?

Meşru müdafaanın şartlarını altı noktada toplamak mümkündür:

I - Taarruz: Hukukan himaye edilen bir varhğa zarar vermek maksadiyle islenen veya islenmekte olan müspet bir fiildir (3). Bunlar, Hafter'e göre teşebbüs derecesinde bir fiil veyahut bir hazırlık hareketi de olabili (4). Bu tecavüzün haksız, olmasi lâzımdır, fakat mutlaka cezayı müstelzim bir hareket olması icabetmez, çünkü meşru müdafaa bir ceza mahiyetini haiz değildir. $O$ ancak bir korunma vasitasıdır. Işte bundan dolayıdir ki cezaî ehliyeti bulunmayan akıl hastaları veya küçüklere karșı da meşru müdafaa caizdir. Bu haksız tecavüzün maddi bir zarara sebep olmuş olması da şart değildir (5), zararm ve tehlikenin halen mevcut ve ciddi olması kâfidir. Bu tecavüz ciddi olmadığı halde, ona maruz kalan kimse ciddi bir tecavüze uğradığı zannına kapılmış ve bu hatası da mazur görülecek mahiyette bulunmuş ise kendini müdafaa maksadiyle yapmış olduğu fiillerde meşru sayllır (6).

(1) Garraud : $\mathrm{Sa}: 12$.

(2) F. Erem : Sa: 607 .

(3) A. Gözübüyük: Sa: 591; Logos meşru müdafaasının bazan bir yapmama bir kaçınma şeklindeki (Omission improprement dite) fiiller karşısında da mümkün olduğunu söyler: Sa; 133.

(4) A. Gözülbüyrük: Sa: 592.

(5) Logas; Sa: 132.

(6) Funk; Sa: 91. 
Fakat hakl, hukuka uygun bir harekete karş1 meşru müdafaa mümkün değildir. Bundam dolayıdır ki aşağıdaki hallerde meşru müdafaadan bahsedilemez:

a - Resmî bir memurun, vazifesi icabı olarak yapmış olduğu hareketlere karși: Fakat umumiyetle resmî bir memurun; keyfî bir hareketinin haksız bir taarruz teşkil edeceği kabul olunur (1). Bununla beraber mesele çok münakaşalıdır, kanunumuz bu konuyu C. K. 258/4 ve 272 nci maddeleri ile hallederek, memurlara karșı gelmenin bir beraat sebebi değil, ancak bir hafifletici sebep olacağını tasrih etmiştir (2).

b - Meşru müdafaa halinde bulunana karșı: Mamafih meşru müdafaada bulunanm bu hakkını suiistimal etmeye başlaması anında; diğer tarafında meşru müdafaa hakkı doğnnya başlar. Çünkü genel olarak $\mathbf{M}$. K. 2 de de tasrih edildiği gibi hukuk; her hangi bir hakkın kötüye kullanılmasını, suiistimalini himaye etmez. Ayni suretle bir kimsenin, kendini yanlışlıkla meşru müdafaa halinde addetmesi veya tehlikeyi gözönünde büyüterek sert bir müdafaa vasıtasına müracaat etmesi mütecavize meşru müdafaa hakkının tanınmasın icabettirir (3).

c. Kanunun bahşeylediği bir hakkı istimal edene karşı: Meselâ zaruret halinde buluman veya B. K. 52/2 deki şartlarm mevcudiyeti halinde kendiliğinden ihkakı hak edene karşı da meşru müdafaa bahis mevzuu olamaz.

II - : Müdafaada zaruret bulunmalı: Müdafaa; tecavüzü önlemek için yapılan her hangi bir fiil ve harekettir. Bu fiil ve hareketler içine ceza hukuku bakımından suç teşkil edenler de girebilir; bunun içindir ki kuvvete ancak o tehlikeden başka türlü kurtulmak imkâm bulunmiyan hallerde müracaat edilmelidir. Zaten sosial nizam; ferdî kuvvete müracaatı da, yalnız bu șartla haklı görür (4); müdafaada zaruret bulunması da bunu ifade eder.

Baska türlii korunmak imkânı bulunmamasından ne anlamak lâzımdır? Aceba mütecavize karşı koymadan kaçmak mümkün olan yerlerde kaçmamak bir suç mu tesskil eder? Bu mesele klâsik ceza edebiyatında uzun münakaşa konusu olmuş ve nihayet her hangi bir kimseye; şerefli bir insan için bir küçüklük ve aciz ifadesi olan kaçma mecburiyetinin yükletilemiyeceği neticesine varılmıştır (5). Mütecavizin ana, baba, küçük bir

(1) Turk ve ttalyan Ceza K. şerhi: Sa: 204.

(2) 1941 - 1942 Yargitay Kararlar: Ceza bölümü Sa: 51 .

(3) E. Arsebuk: Sa: 583 .

(4) Garraud: Sa: 813 .

(5) F. Frem. 609. 
çocuk veya deli olmasının hiç bir kıymeti yoktur, hepsine karşı meşru müdafaa caizdir. Lákin bu görüș tarzı bir az fazla serttir, Domnedieu (1) T, Taner, (2) Garraud (3) gibi hukukçularla beraber şyle bix tefrik yapmanin adaiete daha uygun düstüüü kabul edvoriz: Kahil ve kuv. vetli bir kimsenin; kïcuk bir çoed salkat bir insan voya bir ak11 hastas! tarafundan faam ua uğraması hånde kuvvete müracaattun evvol kạmasl mümkün ise bu son careye basvu nass daha yerndedir, cinkü bu gibi kimseler önünden kaçmakia herhangi bir küçüklük mevzuubahis olamıacağ1 gibi bunlara karșı kahramanlık taslamak da pek övünülecek bir şey değildir.

Mütecavizin ana ve baba olmass halinde de ayni tedbire müracaat edilmesinin daba adilâne olduğunu zannediyoriz (4).

Daha hafif fillerle bertaraf edilmesi mümkün olan tecavüzlere ağır mukabelede bulunmakta da zaruret yoktur, böyie bir riüdafaa halinde zaten müdafaa hududu tecavüz edilmis olur. Meselâ mütecavizin kolunu, elini tutarak, veya onu bir yere kapatarak tecavizden kurtulmak müm-

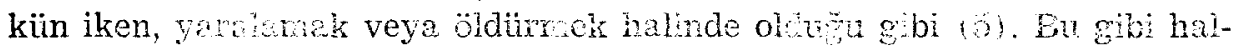
lerde de artık meșru müdafaadan bahsedilmez, belki ancak cezai azaltılan kanunî veya fiilî sebeplerin ortaya çıması dolayısiyle müdafaada bulunanin cezas indirilir.

Tehlikeđen başlsa türı̈u kaçmılmanm mümkün olmaması için kamu kuvvetinin h mayesine sığınmanın da imkânsız olması lâzımdır. Bunun mümkün olduğu hallerde de meşru müdafaa yoktur.

Bir taraftan miidafaada bulunmak için taarruzun başlamasını beklemek şart değildir, mütecavizin hal ve etfarının mağgurda bunun baș. lamış olduğu zehabinı uyandırması kâîdir. Zaten colk defa taarruzun baş lamasını beklemek ona karşı müdafaayı imkânsız hattâ bazanda faidesiz bir hale kor. Diğer tacaftan da baslamıs ve devam etmekte bulunmuş olan taarruza kayg midafaa hakk da dovan eder (6). Teknt son bumus veya mağdurun müdafaası sayesinde tehlikesiz bir hale konmus taarruza karşı müdafaanın devamı kabul olunamaz. Cünkü böyle bir vaziyette artık müdafaa hakkı mevzuu bahis olmaz, mağdur artik intikam hissinin tesiriyle hareket etmektedir. Meselâ kendisini yere düşürdükten sonra kaçanı takip eden kimse, meşru müdafaa iddiasında bulunamaz.

(1) Sa: 238 .

(2) Sa: 394 .

(3) Sa: 814

(4) Garraud: $\mathrm{Sa}: 28$.

(5) H. ömer: Sa: 828.

(6) V. Liszt: Sa: 823 . 
Müdafaada zaruret bulunup bulunmadı̆̆ meselesi failin içinde bulunduğu maddî ve mânevi şartlara göre takdir edilecek çok ince ve önemli bir meseledir (1). Bunun takdirinde objektif bakımindan, mağdurun haksız taarruza karşı koymamıs olması halinde bu taarruzun doğuracağı neticeler nazara alınmakla berber subjektif bakımından da böyle bir taarruz karşısında mağdurum haleti ruhiyesini araștırmak lâzımdır. Hattâ belki de bu sübjektif unsur subjektif olandan daha da ehemmiyetlidir. Çünkü haksız bir tecavüze maruz kalmış olan bir insanın; o andaki helecanı ve korkusu tesiriyle hissettiklerini herhangi bir kimsenin soğuk kanlılıkla kendini onun yerine koyarak muhakeme etmesi pek zordur. Zaten tecavüzde; mütecavizin maksadına göre değil, mağdurun haleti zihniyesine göre tâyin edilir (2).

III - : Taarruzla müdafaa arasında sikı bir bağhlik, bir irtibat bulunmalıdır: Tecavüz ile müdafaa arasında çok sıkı bir illiyet rabıtasının mevcudiyeti lâzımdir. Bu illiyet rabitası bilhassa şu noktaların tespitinde önemlidir :

(a) Zaman itibariyle: müdafaa taarruzun devamı swasinda olmaldır (3). Kanunumuz bunu "filhal" kelimesiyle ifade etmektedir. Yâni müdafaa mevcut olan veya devam etmekte bulunan taarruza karşı yapilmalidrr. Müstakbel veya muhtemel (4) taarruzlara son bulinus taarruzlara karşı meșru müdafaadan bahsedilemez. Fakat bu kaşlangıc ve son bulma noktaları nasıl tâyin edilecektir? Bu hususlar hakkında kat'î kaideler koymağa imkân yoktur; bunlar her hâdiseye ve tecavüzün mahiyetine göre ayrı ayrı tetkiki icabeden maddî birer vâkıadır (5). Unumîn olarak denilebilirki taarruza uğrayan kimse, bu taarruzun neticesini beklemiye mecbur değildir, kendi için muhik bir tehlikenin mevcudiyetine kani olduğu anda müdafaaya gecebilir. Başlangıc anının tesbitinde mağdurun, haleti ruhiyesi, yașı ve hattâ cinsiyeti mühim rol oynar.

Taarruzun bittiği anın da ayni esaslar dairesinde tesbiti lâzım-

(1) Garraud: Sa: 207. H. Gözübüyük: Sa: 592 .

(2) H. Ömer: Sa: 823 .

(3) Garraud, Sa: 25, F. Erem: Sa: 611.

(4) Muhtemel bir hâdiseye karşı meşru müdafaanın kabulü; cemiyeti daimi bir huzursuzluğa mahkûm etmek olacaktı: Garçon: Sa: 813. Bununla beraber tesirlerini muhtemel tehlike anında vücuda getirmek üzere tedbirler almak mümkïndür: Logos: Sa: 132, Liszt: Sa: 213. Fakat bu mesele yazarlar arasında münakaşalıdır.

(5) Garraud: Sa: 26. F. Frem 611. 
dr. Umumiyeis mütecavizi artık zarar vermiyecek bir vaziyete getirmék, onu kaçmağa mecbur etmis bulunmak veya elindeki suç aletini almiș olmakla taarruza son bulmus göziyle bakılabilir. Ve bundan sonra yaplan muidafaalar da artik meșru müdafaa sayılmaz (1).

Bununla beraber taarruzun devamindan veya tekrarindan kuvvetle süphe edildiği müddetçe müdafaa hakkı da devam eảer. Hasimı hakkında açıça fena hisler beslediğini meydana vuran bir kimse, elinde tehlikeli bir silâhla serbest brakilamaz (2).

b - Müdafaa mutaarrıza karșı olmalıdır: Taarruza karışmıan bir üçüncü şahsa müdafaa sırasında, ika edilen zararlar meșru müdafa olarak kabul olunamaz (3), ve üçüncü şahsın bu suretle zararını mucip olan kimse halin icaplarına göre; zaruret hali müstesna; ihmalinden dolayı mahkûm olabilir.

c - Taarruz ile müdafaa arasında nispet: Bir tecavüze maruz kalmis olma, buna her ne suretle olursa olsun karși koyma salâhiyetini vermez. Bundan dolayıdır ki meşru müdafaanın şartları ile, müdafaanm hududu derecesi birbirine sıkı, sıkıya bağlı olan şeylerdir (4), (5). Mütecavize karşı kullanlacak kuvvet, tehlikeye mâni olabilecek veya ondan kưtulmayı mümkün kılacak nispette olmalıdır. Loire ağır ceza mahkemesi bahcesinden meyve çalan bir adamı tabanca ile öldüren bir sahsi haklı olarak mahkûm etmiști (6). Tehlikeden kurtulmayı mümkün kllacak nisbetteki bir kuvvet; mütecavizin yaralanmasina ve hatta ölümünü intacetmis olsa bile ona müracaat edene bir mesuliyet atfedilemez

Esas itibariyle bir müdafaa vasitası olan messri müdafaa bazı hallerde messru bir tecaviuz vasstası da olabilir (7).

(1) Eve girerek taarruzdan kurtulan bir kimsenin silâll!a digardakilere ateş etmesi kendisini mütccaviz vaziyetine sokacağndan C. K. 49 hijkmü tatbik olunamaz: 1939 - 1940 Temyiz Kararları ceza kısmı Sa: 99.

(2) Kenny: Fransızca tercümesi: Sa: 135; cekígi tabsncann dişüüumesinden sonra bıçak çekin kimseye yeniden midafaz hakki meydana gelir: Yargitay kararları: Ceza bölümü: 1941 -1942: Sa: 51.

(3) H. Tan: Sa: 201; Landon: Sa: 135

(4) Garraul: Sa: 17; Logos; Sa: 134 .

(5) C. K. mizda müdafaamm hududunun aşlmasin 50 inci maddesiyle müeyyideye bağlamıştur.

(6) Donnedieu: Sa: 238.

(7) Kenny: Sa: 117; Size karşı cevrilmiş bir silâhı bastonunuzun bir darbesiyle yere duistürmek gribi. 
Tecavïz ile müdafaa arasındaki nispetsizlik aceba mütecavize mukabil harekete geçmek hakkını verir mi? Buna müsbet cevap vermek lâzımdır (1). Zira meşru müdafaa hakkının sınırlarının așilması bizatihi bir haksızlı teskil eder, kendisine bir tokat vurulan bir şahsın mütecavize karş1 tabanca çekerek onu öldürmeye teșebbüs etmesi halinde olduğu gibi. Fakat tecaviuz ile müdafaa arasıda aranlan bu nispeti yani; müdafaa ile müdafaanın aşılması arasındaki hududu tespit çok güçtür. Bunu tâyin ederken fazla formalist davranmamak ve tecavüze maruz kalanın o andaki ruhi haletini gözönünde tutmak lâzımdır (2). korku, șașkınlık ve dehşet tesiriyle hareket eden bir kimseden soğuk kanl bir muhakeme ile böyle bir nispeti düşünerek hareket etmesi beklenemez; zaten hâkim de her hâdisede; bu hâdisenin hususiyetlerini dikkat nazarma alarak karar vermek zorundadir (3). Müdafaadaki nisbetsizliğin sabit olması müdafaada bulunana ancak cezayı azaltıcı sebeplerden istifade hakkı verebilir.

(IV) - Taarruz hukukan himaye edilmis bir varliğa (bien juridique) karşı yapılmıs olmalıdır: Aceba her türlü hakka karşı yapılan taarruz müdafaayı meşru kılar mı?mal için müdafaa caizmi dir? ?Bilhassa bu son nokta ceza hukukunda çok münakaşalı bir mesele olduğu gibi bizim hukukumuz bakımından da çok önemli ve ihtilâflı bir mevzu teşkil eder.

Meşru müdafaayı haklı gösterecek, ona mevzu olabilecek haklar zamanla bir tekamül geçirmiștir.

a - Eski Yunanistan, Hint ve Romada meşru müdafaa ancak hayata șerefe ve haysiyete karșı vâki tecaviuzler hakkında kabul edilmiş ve bazı şartlar altında da hırsızlığa (yani mallara da) teşmil edilmişti. 12 levha kanunundaki "furum manifestum" hallerindeki hırsızlı̆ga karşı böyle bir müdafaa caizdi (4).

b - Orta zamanlarda böyle bir müdafaa hıristiyanlı̆̆n tesiriyle yalnız hayata karşı yapılmış olan taarruzlar için meșru addedilmişti.

c - 18 inci asır sonlarında meşru müdafaanın sahası daha ziyade genişleyerek bütün haklara karşı yapılan tecavüzleri içine almağa başladı̆̆ gibi, o vakite kadar yalnız cana (adam öldürme suçu) karşı yapılan suçlarda mevzuubahis olması itibariyle ceza kanunlarının hususi hükümleri arasında yer almış iken sonraları kanunların umumi hükümler kısminda görülmeğe bașladı. Bununla beraber bu hususta ceza kanunlar

(1) H. Tan: Sa: 293 .

(2) Garçon: Sa: 814, Logos: Sa: 134.

(3) Garçon: Sa: 418.

(4) T. Taner. Sa: 636, Magnol: 309.

(5) T. Taner. Sa: 636, Magnol: Sa: 309. 
arasında bir sistem birliği yoktur. Meșru müdafaaya, Fransız (M. 328) ve Belçika Ceza Kanunları adam öldürme (katil) ve müessir fiiller bahsinde temas eder. Fakat bütün Fransiz yazarları onun daha sumullü bir mahiyeti haiz olduğunu ve bütün diğer suçlarda da (infraction) tatbik edilmesi lâzımgeldiğinde hem fikirdirler (1), (2). Alman, İsviçre, İsveç, Ispanya, Hollanda kanunları (3) Türk Kanunu gibi meşru müdafaaya umumî hükümleri arasında yer vermișlerdir.

Fransız kanunu ve diğer bazı kanunlar meșru müdafaadan umumi olarak yalnız sahsın müdafaası bakımından bahseder ve hususi bir madde ile malların da kanunda tesbit edilmiş muayyen hallerde müdafáa edilebileceğini kabul ederler (4).

Türk ve eski italyan ceza kanunu da bu meyandadr. İspanyol ve Holanda kanunları gibi diğer bazı kanunlar meșru müdafaaya mevzu olabilecek hakları teker, teker sayarlar, diğer bazıları ise meşru müdafaayı böyle bir tahdide tabi tutmiyarak yalnız bu müdafaanın prensibini vaz etmekle iktifa ederler, Almanya, Avurturya (5) ve Isviçre kanunları gibi. Meşru müdafaa; diğer beraat ve muafiyet sebepleri gibi Ingiliz ceza hukukumun yazılı olmayan kısmı arasındadır. Ingiliz hukuku, meşru mudafaaya gerek insanın kendi șahsiyetine ve gerekse yakınlarına, (çocuklar, ișçiler) ve mallarına (menkul veya gayri menkul) karși yapilan haksiz bir taarruzun kuvvetle definde zaruret bulunduğu hallerde müracacaat edilmesini kabul eder. Kenney halen İngiltere'de de bu hakkın müdafaaya muhtaç her hangi bir kimseye yardım içinde meşru olarak kullanılmasının mümkïn olduğunu söyler (6). Lâkin kuvvetle tecavüz arasında bir nispet bulunmalıdır, bununla beraber böyle bir tehlike karşsinda bulunan kimse bu tehlikeye karşı koyabilmek için makul olarak lüzumlu gördüğü bütün kuvveti sarf edebilir (7). Tecavüz ile inüdafaa arasındaki nispet muhafaza edilerek yapılan bir müdafaada mütecavizin öldürüulmüş olması müdaafiin cezalandırılmasını intaç etmez. Fakat mal için tanınmıs olan müdafaa hakkı hiç bir zaman mütecavizin öldürülmesine kadar vara$\operatorname{maz}(8)$.

(1) Garraud: Sa: 15.

(2) Zaten yeni Fransız Ceza Kanunu projesi onu umumi hükümleri arasına koymaktadir. Garraud: Sa: 15.

(3) İbid.

(4) Ibid.

(5) İbid.

(6) Kenny: Fransizca tercümesi: Sa: 132.

(7) Ladon: Sa: 134; vd.

(8) Kenny: Sa: 118, va. 
Prensip olarak haksiz bir tecavüzün insanlarin şahsina, hürriyetine serefine, urzma müteveccih olması halinde meşru müdafaayı kabul icabeder. Fakat hayattan gayri diğer haklara ve hususiyle mülkiyete yapılan tecavïzlerde müdafaa hakkının meşru olup olmayacağı meselesi türlü içtihatlara ve telâkkilere yol açıştır (1). Bu husustaki görüişleri iki kısımda toplamak mümkündür :

1 - Meşru müdafaa yalnız şahıslara karşı yapılan tecavïzlerde caiz olmalıdur. Bu fikir Grocius, Primus gibi yazarlar tarafından ileri sürülmüş̧ü (2). Bu görüşü müdafaa edenler ve bilhassa Grocius, insan hayatının dünyada mevcut bütün varlıklardan daha üstün olduğu düşüncesinden hareket eder ve meşru müdafaanın ancak telâfisi mümkün olmayan zararlara, insanın hayatına, mevcudiyetinin bütünlüğüne karşı vâkı tecavüzlerden doğan zararlara hasredilmesine ister. Çünkü diğer haklara ve bilhassa mülkiyete karşı yapılan tecavüzlerden husule gelen zararlarin salâhiyetli makamlara müracaatla hirsızın yakalatılması veya insanın yeniden çalışması suretiyle telâfisi mümkündür. Zaten bu gibi vaziyetlerde ihtilâf halinde bulunan haklar arasında da müsavat yoktur. Husule gelen zarar mütecavizin öldürülmesini haklı gösterecek kadar ağır da değildir. Bu görüş tarzı kolaylıkla tenkit edilebilir. Bunun tarafları meşrû müdafaanın her türlü ölçüden uzak bulunduğu zehabına istinad etmekte (3) oldukları gibi meşrû müdafaanm mevcudiyeti ile onun șartlarmı da yekdiğerine karıştırırlar.

Diğer bir takım yazarlar mal için müdafaanın meşru olmıyacağını izah için, meşrû müdafaanın manevi cebir fikrine dayandığı noktasından hareket ederler. Böyle bir duruma düşen kimse; şahsını, mecudiyetini koruma sevki tabiisiyle hareket eder. Halbuki mal için vâki tecaviuzlerde böyle bir hal yoktur (4). Fakat bu noktainazar baskasinın hayatına, Irzına karşı vâki tecavüzler için meşrû müdafaanın neden kabul edilmiş olduğunu izah edemez; bundan başka bazı hallerde mala karșı yapılmıs tecavüzlerde, mal sahibinin irade ve hareket serbestisini ortadan kaldırabileceğinden bu gibi vaziyetlerde mal için müdafaanın da meşrû olacağını kabul zorunda kalırlar. Lâkin bugün müdafaada manevî cebir esası tamamen terkedilmiştir, tecavüze maruz kalan kimse-

(1) T. Taner: Sa: 631.

(2) F. Erem: Sa: 614 .

(3) Donnedieu: Sa: 235.

(4) T. Taner : \$a: 634 . 
nin iradesinin selbedilmiş olması şart değildir. Soğukkianlılıkla kendisini müdafaa etmiş olanin da bu hareketi meşrudur (1).

2 - Meșru müdafaa diğer haklarda ve bilhassa mülkiyet hakkmda da carî olmalıdır; çünkü devletin, vatandaşlarının hakkını koruyamadığı hallerde vatandaşın bizzat kuvvete müracaat etmesini kabul elzemdir Kanta göre de, şahsa çok yakinen bağlı olan hakların taarruza uğraması halinde meșrû müdafaanm tanmmasi icbeder, mülkiyet bu haklarm başında gelir (2).

Mala yapılan tecavüzlere karş müdafaanın caiz olup olmadığınm şimdiye kadar böyle uzun mïnakaşalara yol açmassının en belli başl sebeplerinden biri de mala yapılan ufak bir taarruzun siddetli bir müdafaa ile defedinresinin hakl gösterilemiyeceğinden ileri gelmektedir. Fakat hakkm meveudiyetinin tanınması ile onun ölȩïsü, hududunun tahdidi bașka, başka şeylerdir; zaten hakkın kötü kullanılmasının bașladığı yerlerde hak ortadan kalkar, hukukan himaye edilmez. Şu halde diğer bütün hukukî varlıklara (bien juridique) karşı yaplan taarruzlara kuvvetle kars koymak meșrû olduğu gibi mal için de müdafaa meşrûdur. Meșrû olmayan șey tecavüzle münasip olmayacak derecede ve șekilde kuvvet istimalidir (3).

Garraud ve Kenny gibi yazarlar; prensip olarak mal için meşrû müdafaayı, haksı tecavüz ile müdafaa arasındaki nispetin aşlmamıs olmasi șartiyle kabul ederler (4).

Netice olarak diyebiliriz ki ; gerek kendisinin ve gerekse başkasinın hukuken himaye edilmiş bir varlığına karşı vâki haksız taarruzları defi maksadiyle; sartları mevcut olduğu takdirde; hukuken tespit edilmis hudutiar dahilinde kuvvete müracaat messrûdur.

Mal iẹin meșru müdafaay kabul etmis olan yabane kanunlar:

Ingiliz hukuku menkul ve gayrimentullerde meșru midafaay halin icaplarma uygun kuvvet sarfedilmis olması sartiyle kabul edor (5).

(1) Ibid.

(2) F.Eren : Sa: 615 .

(3) T. Tanc: : Sa : 633; Garçon: Sa: 817 : Fakat malikin çok küụik değerdeki bir malını müdafaa için mütecavizi öldürmesi, ağır surette yaralaması bir bera. at sebebi teşkil edemez; çünkü artık bu fiiller intikam hissiyle isslenmiștir; intikam. hissi de meşrû değildir.

(4) Garraud: Precis: Sa: 64; Kenny: Sa: 118 vd: Mala karş vaki tecaviialarda meşrâ müdafaa; ancak mutedil bir juvvet kullamlmasi halinde mümkündür. Eakat mütecavizin öldirülmesine kadar varan miłlafaa hic bir zaman mesma değildir (5) Kermy: sa $11 \%$ T. Taner : 636. 
Holanda Ceza Kanunu 41 inci maddesiyle sarih olarak mal için müdafaayı meşru addeder. "Kendisinin veya baskasının hayatına, şerefine veya mallarına vukubulan haksiz ve ani bir ta'arruzu defi zaruretiyle işlenen fiillerden dolayı failine ceza verilmez" (1).

Yeni İtalyan ceza kanunu mallara karș vaki tecavüzler için 52 nci maddesiyle meşrû müdafaayı "her hangi bir kimsenin haksız bir taarmuza karşı kendisinin veya bir başkasmın hakkmı müdafaa halinde, müdafaa ile tecavüz arasinda bir nisbet bulunmak şartiyle" bütün haklar için öngörülür (2). 1942 de meriyete giren Isviçre Kanunu da 33 üncü maddesiyle meşrû müdafaayı her nevi hakka ve bu meyanda mülkiyete karșl vaki tecavüzlere de teşmil etmiştir. Tecavüze maruz kalan malın (bien) kıymeti ancak meşru müdafaanın ölçüsünü tayin bakımından önemlidir (3). Danimarka, Lehistan, Alman (4) ceza kanunları da her türlü haklar için meşru müdafaayı kabul ederler. 1934 tarihli Fransız ceza kanunu projesi de mallara karşı vâki tecavüzler için müdafaayı meşru saymaktadır.

1810 tarihli ve halen meriyette bulunan Fransız ceza kanunu mal için meşrû müdafaayı; bazı istisnaî hallerde; şahıslara karşı zor ve cebir kullanlmak suretiyle yaplan 329 uncu madedsinde gösterilen tecavüzler için kabul eder. Bütün Fransız cezacıları tarafından genel bir hüküm olarak kabul edilen 328 inci maddenin mülkiyet için meşru müdafaayı mümkün kılı kılamıacağı meselesi Fransada da münakaşalıdı (5), (6).

\section{Türk Hukukundaki Vaziyet :}

Acaba Türk hukukundaki vaziyet nasıldır? Meseleyi iki kısma ayırarak bir ceza kanunu bakımmndan ve bir de medenî kanun hükümleri bakımından inceleyeceğiz :

\section{A - Ceza kanunu bakımindan :}

Ceza kanunumuz meșru müdafaa hakkındaki umumî prensibi 49 uncu maddesiyle koymaktadır. Bu macle yalnız "gerek kendisinin ve gerekse başkasının nefsine ve ırzına vukubulan bir taarruzdan" bahsedil-

(1) Göziübüyừk : Sa: 596.

(2) E. Erem: Sa: 616; T. Taner: Sa: 638 .

(3) Logos: Sa: 133 .

(4) A. Gözübüyük: Sa: 596.

(5) A. Donnedieu: Sa: 243, Garraud: Sa: 23 - 24; 329 uncu maddedeki meșru müdafaanı mülkiyet hakkına da teşmilini kabul ederler.

(6) Garçon Garraud'nun bu görüsüune muhalif bir görüștedir; Sa: 324; Magnol da mülkiyet için meșru nüdafaunın kabul edilmemiş olduğunu bunun bir istisnasın teşkil eden 329 uncu maddenin de şahisların himayesi mülâhazasiyle knnmuş oldutrunu söyler : $5 a$ : $315 \mathrm{vol}$ 
mektedir. Kulianılmış olan tabirler sarihtir, yalnız nefis ve 1rz. Nefis tabiri ne kadar geniş bir tefsire tabi tutulursa tutulsun bunun ancak şahsin tamamiyetine karşı yapılmış olan tecaviuzlere teşmili kabil olsa bile mallara karş yaplmıs taarruzlara kadar genişletilmesi mümkün olamaz. Zaten metnin asil olan eski Italyan kanununda da "kendisine" kelimesiyle daha geì $\$$ bir surette ifade edilmis olan bu mefhumun mallara karşı yapilan tecavüzlere samil olmadiğl kat'i ve muhakkak surette kabul edilmiști (1). Binaenaleyh bu madde ile mal için meşrû müdafaa kabul olunmamıstır. Ceza kanunumuzda meşrû müdafaanın hususî bir tatbik şekli diyebileceğimiz bir de 461 inci madde vardır. Acaba mal için yapılan müdafanın meşrû olup olmadığı meselesinin hallinde bu maddeden istifade eciemez miyiz?

Bu maddede; her nekadar mala karșı yapulan taarruzları istihdaf etmekte ise de müdafaayı münhasiran menkul mallara yapilan tecaviuz.lere hasreylediăi gibi ancak cebir ve siddet kullanlarak ve baskn seklindeki tecavüzlere karșı kuvvetle koyma halinde muafiyet tanımaktadur.

461 inci maddedeki hükümler iki kısımda toplanabilir :

a - Bir menkul malın malikine malını cebir ve şiddet istinaliyle gasbı yani yağma'sı halinde tanınan malını zor kullanarak müdafaa hakkı (2), yani C. K. $495 \mathrm{vd}$. maddelerinde gösterilen tecavizlere karş tanınmıs bir müdafaa hakkıdır. Her ne kadar 461 inci madde "kendi mailn" tabirini kullanyor'sa da bu madde başkasina ait malın müdafaasinda dahi tatbik olumur (3). Su halde bu madde ile zilyede de müdafaa hakkının tanınmıs olmasinı kabul yerinde olsa gerektir.

b) Ị̇indekilerin şahsî emniyetlerine aklen varit bir endiṣe veva havfi ciddî, verecek surette bir meskene tecavüz halinde $461 / 2$ deki müdafaa hakkı, fıkradan da anlaşlacağı üzere şahısların emxiveti icin bir tehlike mevcut oldığu hallerde istimal olunabilir.

Ceza kanunumuzda meşrû müdafanın hususî bir tatbik șekli diyebileceğimiz bu maddeden bașka bir hüküm yoktur. Fakat bu da; müdafaayı ancak muayyen sartların mevcudiyeti halinde kabul eylediği gibi müdafaaya geçmok için taarruzda cebir ve şiddeti veya şahsî emniyetin tehlikede bulunmasmı esasl bir unsur olarak kabul eder. Su halde aca-

(1) T. Taner : Sa : 642 .

(2) T. Taner't göre de: $461 / 1$ de gösterilen suçların her birinde cebrui şiddet ve tehdit unsurı meveut olduğundan kanun șahsiyete karș bir tecaviizüin bulunması halinde malın midafaasın tecviz etmiştir. Sa: 643. Ceza K. serhinde de (Türk - Italyan ayni fikir mevouttur. Cilt: 3, Sa: 272 .

(3) Cokt K. Gerhi (Tirk, Italyan) dilt : 3 ; Sa: 272. 
ba hukukumuzda mülkiyete âdiyen vâki taarruzları; meselâ âdi hırsız$l k$, yankesicilik veya şahsî emniyeti tehdit etmeden gayrimenkullere yapılmış tecavüzleri, meşrû müdafaa yoliyle önlemek mümkün değilmidir?

Böyle bir müdafaa hakkına diğer kanunlarda bilhassa medenî kanunda genis bir yer verilmiştir.

\section{B - Medenî Kanunun hüikümleri bakammdan:}

Medenî Kanunumuz zilyetliğe ve dolayısiyle mala karşı vaki tecavüzlerin kuvvetle define 894 üncü maddesiyle zilyetliğin bizatihi himayesi dolayısiyle temas etmiş, Borçlar Kanununun 52 inci maddesiyle de bu müdafaanın șahsî hukuk bakımından doğacak neticelerini tanzim etmiştir. Zaten Von tuhr ve Arsebüğün de beyan ettikleri gibi 52 nci madde ile tespit edilmiş olan meşrû müdafaa hakkı mameleğe dahil olan diğer haklardan daha ziyade zilyetliği himaye etmektedir. (1).

Bir şey üzerinde fiili bir kudrette sahip olmak o șeyden bir menfaat temin etmek demek olan zilyetlik; hukukan himaye edilmiş fiili bir durumdur. Zilyetlik müessesesinin hukukan himayesi, cemiyet içindeki asayiş ve sükûnun devammı mümkün kılar. Şey üzerindeki bu tasarruf ve fiili kudret sahibine şeye karşı vâki her türlï yabancı müdahaleyı bertaraf etmek yetkisini de bahşeder. Cemiyetin nizam ve sükûnunun devamını temin eden bu müesseseyi, her türlü tecavüz ve müdahalelere karși müdafaa eden zilyet, hem bizzat kendi hakkını ve hem de cemiyet içindeki intizamm devamm temin suretiyle Ferr'nin de söylediği gibi cemiyet menfaatine uygun bir iş görür (2), (3).

894 üncü madde zilyede bütün gasp ve tecavüz fiillerini kuvvet kullanarak defetmek hakkını verir. Şiddetle veya hafiyyen kendisinden alınan o sey gayrimenkul ise zilyet gasbı kovarak, ve menkul ise cürmü meşhut halinde tutulan veya kaçarken yakalananın elinden tamamiyle geri alarak istirdat edebilir.

Zilyede bu madde ile tanmmıs olan müdafaa hakkmm mahiyeti ve şumülï nedir? Zilyet hangi sartlar altında bu haktan istifade edebilir?

I - Bu haktan kim istifade eder? Prensip olarak müdafaa hakkı gerek aslî zilyede ve gerekse fer'i zilyede arada bir fark gözetilmeden tanımıştır. Fakat acaba hizmetçi ve ișci gibi diğerlerinin emirlerini

(1) Von Tuhr Sa: 332, Arsebük, Sa: 581.

(2) F. Erem: S: 619 .

(3) Zilyet bizzat kendi hakkında müdafaa etmis olur, çinkü M. K. 898 ve $899 \mathrm{mu}-$ cibince zilyetlik aynj zananda hakka da bir karine teşkil eder. 
ifa eden ve baskasinin malina muvakkaten bu hizmeti ifa dolayısıyle tasarruf edenlere de (auxiliaire de la possession, tasarruf vasitasi, vazıülvet) bu hak tanınmis midır (1) ? Tuor bu gibilerin 894 üncï maddededeki haktan istifade edemiyeceklerini onlar hakkında ancak B. K. 52 inci maddedeki meșrû müdafaanın veya zaruret halinin bahis mevzuu olacağ1nı kabul eder (2).

Belgesay da; bu gibi kimselerin zilyet lehine olan hükümlerden istifade edemiyeceğini, onlarm malın muhafazası için kendi namlarına değil fakat ancak zilyet namina cebir ve siddet kullanacaklarmı söyler (3).

894. üncü maddedeki bu müdafaa hakkı bizatihi doğrudan doğruya zilyedliğin himayesi bakımından bahşedilmiş bir hak olduğundan fer'î zilyet, zilyetliğini aslî zilyede karşı da zor kullanarak müdafaa edebilir. Vâziülyetlere üçüncü şahıslara karşı böyle bir müdafaa hakkı tanınmış olsa bile bu hakkı şeyi kendilerine vermiş olan asıl zilyede karşı hiçbir zaman kullanamazlar, fakat zilyet seyi; vaziullyetlere karșı zor kullanmak suretiyle her vakit geri alabilir (4).

II - Zilyet müdafaa hakkmn ancak maddede tasrih edilen hallerde yani zilyetliğin hafiyen veya siddetle gasbı halinde icra edilebilir. $\mathrm{Bu}$ iki tabirden neyi anlamak lâzımdır? Gasp fiili; keyfî olarak yani asıl zilyedin ruzasi olmadan veya onun rizasina rağmen islenmiș olan hareketleri anlatır (5). Gasp edenin kusurlu olup olmaması o sey üzerinde bir hakkı bulunup bulunmaması bir rol oymamaz.

Gasbı Willand şöyle tarif etmiştir : Baskkasının zilyetliğine, hakhı gösterilecek bir sebep olmaksızın zilyedin rızası hilâfına yapılan tecavïzler (6). Aslî zilyede karşı zor kullanma hakkını meşrû gösteren de işte budur. Meselâ ev sahibinin herhangi bir haklı sebep olmadan kiralanan yere (mecura) girmesi ve kiracının ihtirarına rağmen çlkmaması halinde; kiracinın onu zorla kolundan tutup dıșarı atması haklıdır.

Hafiyen alınma içine de ; ceza kanununun hırsızlık, yankesicilik ve emniyeti suistimal sucları girer.

(1) M. K. Belgesay : Sah : $343:$ Bu gibi kimseler zilyet değildir; Wieland : Sa: 362; fakat Alman hukukunda onlara da müdafa hakkı tanınır. Pesish : Sa : 416.

(2) Tuor: Sa: 406; Willand aksi fikirdedir: Sa: 391.

(3) Belgesay : Sa: $341,346$.

(4) Belgesay : $\mathrm{Sa}: 341$.

(5) Hirş: Sa: 781 .

(6) Wieland : Sa: 388 .

(4) Hirs: : 59: 781 . 
Şu halde umumî olarak diyebiliriz ki zilyedin rızası olmadan veya rızasına rağmen onun zilyetliğini gasp veya ona tecaviuz eden kimse umumî sükûnu ihlâl ettiğinden objektif bakımdan daima haksız surette hareket etmiş olur ve bu haksız tecavïz karşısında da kendisine kuvvetle karșı konulabilir. -Fakat șu hallerde meșrû müdafaa caiz değildir.

a - İdarî makamlarla memurlara kanun tarafından tanınan bir mahalle girme veya bir mala vaziyet etme salâhiyetlerine karşı,

b - Bir kimseye B. K. 52 nci madde mucibince tammmıs olan kendiliğinden ihkakı hak ve zaruret hallerinde.

c - B. K. 57 mucibince bir gayrimenkul zilyedine tanımıs olan, gayrimenkülüne zarar ihdas eden hayvanlar üzerindeki hakkını istimal halinde,

d - B. K. 267 mucibince kiralayanın haiz olduğu hapis hakkinı istimaline karş.

III - Bu hakkın şümulï Medenî Kanunun 894/2 maddesiyle tespit edilmiştir. Gayrimenkullere vâki tecaviuzlerde zilyet tecaviuzde bulunan kovmak hakkımı haizdir. Zilyedin bu kovmasına rağmen mütecavizin çlkmamakta ısrarı halinde ınu kolundan tutup dışarłya atmak ve halin iacebttirdiği kuvveti sarfetmek salâhiyeti vardır. Zilyedin bu hakkını kullanması için mutlaka bu tecavïzden zarar görmesi de şart değildir. Zilyedliğin haksız olarak ihlâl edilmiş olması kâfidir.

Menkul mallarda; zilyet gasp ve tecavüz fiillerinin devam ettiği müddetçe veyahut da mütecavizi kaçarken yakaladığı müddetçe malımı geri almak için kuvvet kullanabilir. Kanun tecavüzün devam ettiği müddettabirini cürmü meşhut halinde yakalamak suretiyle ifade etmiştir. Müdafaa hakkı hâlen mevcut zilyetliğe her türlü gasp ve tecaviuz fiillerinin neticesiz kalmasın temin edinceye kadar devam eder. Curti-Furrer cürmü meşhut tabirine oldukça geniş bir mahiyet vererek bir kimsenin paltosunu çalan bir șahsı demiryolu durağında fakat hırsızlıktan birkaç gün sonra yakalaması ve orada da polis memuru bulunmaması halinde bu hırsıza karşı müdafaa hakkını kullanabileceğini kabul eder(1). Rossel ise aksi fikirdedir: "Kuvvet hemen gasp veya sair tecaviuzün vukuu anında icra olunmalıdır, bundan sonra zilyet ancak dâva açabilir" der (2). Bize de bu fikir daha uygun gelmektedir. Çünkü müdafaa ile

(1) Curti Gurrer : Türkçe tercimesi : Sa. : 604.

(2) H. Oner : Sa : 835 . 
tecavüz ve ihlâl arasında aramlan bu zaman münasebeti zilyedin kuvvete müracaat hakk verilen yerlerde kısa olmak icabeder (1).

Fakat mütecavizin zilyetliğe mevzu teşkil eden şeyi yakalayıp kaçmağa başlaması halinde de müdafaa hakkı devam eder mi? Kanununumuzun kaçarken tabirini ne şekilde tefsir etmek lâzımdır? $\operatorname{dir}(2)$.

Ourti'ye göre bu kaçarken tabirine de çok dar bir mâna verilmeli

Tuor bunun tecavüzün akabinde ve tecavïz ile eski halin iadesinin tek bir fiil teşkil etmesi hallerine hasrı fikrindedir.

Belgesay: "Șüphe yok ki mütecaviz, zilyedin nüfusu altındaki mahalde yakalanmıs ise hakkında cebir istimal olunabilir, fakat bize göre, ahval ve seraite nazaran mutearruz kendisini takipten vareste addedebileceği dakikaya kadar kaçmakta addolunur" (3) demek suretiyle bu flkrayı çok sumullendirmiştir.

IV - 894 üncü maddenin son fikrası zilyede tanınan bu hakkı zilyedin suiistimal etmesini önlemek maksadiyle, onu halin haklı göstermediği cebir ve şiddeti kullanmaktan menetmiştir. Zilyet malın aynî kıymeti ile mütecavizin melhuz olan kastını nazarı itibara almak zorundadır (4). Lâkin bu mesele umumiyetle her hadisenin kendi hususiyetleri göz önünde tutularak takdir edilir. Tecavïz ciddi olmadığı halde, ona maruz kalan kimse ciddî bir tecavüze uğradığı zannına kapılmıs ve bu hatası da mahzur görülecek mahiyette bulunmuş ise kendini müdafaa maksadiyle yaptı̆̆ı fiiller meşrû müdafaa sayılır (5). Bu hududu tecavüz eden zilyet, hususî hukuk bakımından bir haksız fiil işlemiş olması dolayısiyla tazminatla mahkûm edilebileceği gibi cezaî mesuliyeti de haiz olur. Fakat müdafaa hakkının hudutları içinde kalan zilyede ne hususî hukuk ve ne de ceza hukuku bakımından bir mes'uliyet terettüp etmez.

894 üncü maddenin şimdiye kadar tahliline çalıștığımız unsurları Ceza Kanununun 49/2 inci maddesiyle tesbit edilmiş olan meşrû müdafaanınkilere tekabül etmekte olduğu kamaatındayiz. Burada en son oiarak söyle bir sual varit olabilir :

(1) H. C. Oğuzoğlu : Sa : 68; A. Artus : Sa : 347 .

(2) Curti Furrer : Sa : 604.

(3) Belgesay : Sa : 350 .

(4) S. g. e : Sa : 351; Von Tuhr da az kıymetteki malları müdafaa için mübalagalı derecede kuvvet kullanmanın müdafaa hakkının sui istimalini teşkil edeceğini kabul eder : Sa : 334 .

(5) Funk : Tinlog: torcimesi : Sa : 91. 
Medeni Kanununumuzun 894 üncü maddesindeki bu müdafa hakkını son fikrasında gösterilen hudutlar dahilinde istimal eden bir ziyledin müdafaa sırasında yapmış olduğu ceza hukuku bakımından sụ teşkil eden bir fiilden dolayı kendisine cezai mesuliyet tahmil edilebilir mi? Başka bir deyișle kanunun verdł̆̆i bir salâhiyeti kullanan böyle bir kimse cezalandırılmalı mıdır? Bu mesele bilhassa tatbikatta çok münakaşaIıdır. Ceza kanununun mal için meşrû müdafaa kabul etmemiş olduğu ileri sürülerek ekseri böyle bir kimsenin C.K. 49 daki beraet sebebinden istifadeye hakkı olmadığı ve ceza hâkiminin medeni hukuk hükümlerini gözönünde tutmak zorunda bulunmadğı ileri süruilür. Zilyedin bu haksiz tecavüzü def'e çalişırken zora müracaat etmis olması ceza kanunu bakımindan bir suç teşkil ediyorsa mahkûmiyeti cihetine gidilerek ancak cezası tahrik veya takdiri azaltıcı sebeplere dayamlarak indirilir. Fakat bu sekildeki bir hareket tarzının pek de âdilâne olduğunu zannetmiyoruz. Çünkü hukukumuzda cęa hakiminin yalnız ceza kanunlarını tatbik edeceği yolunda bir hüküm mevcut olmadığı (1) gibi bir Devletin içindeki bütün kanunlar ve örf ve âdlet hukuku bir kül halinde o Devletin pozitif hukukunu teşkil eđeceğinden hakim bütün mevzuatı gözönünde bulundurmak zorundadır. Zaten herhangi bir kanunun sarih veya zmmi müsaadesine dayanan hareketler de suç sayılmaz (2).

Magnol da ceza kanununun tasrih eylediği beraet sebeplerinden başka, fail lehine gerek ceza ve gerekse hususî veya idarî kanunlarda mevcut bir beraet sebebinin de tatbik edilmesi lâzımgeldiği kanaatindedir (3). Böyle bir muafiyet veya izin sarih veya zimni bile olabilir:

Mahiyetleri bakımundan esas itibariyle cezaî müeyyede altına alınmis fillerin ve hareketlerin yapilmasını istihdaf eden meslek ve sanatlarin icrasına kanunun müsaade etmesi halinde; bunlarm ceza kanununun haricinde kalmasını tervic etmiș olduğunun kabulü lâzımdır ve bu gibi hal-

(1) Erem : Yargitayın içtihatlarının hususi hukuk kaidelerinin ceza hukuku sahasına intikal imkânını kabuletmiş olduğunu söylemektedir : Sa : 623; Ceza heyeti umumiyesi de Antalya Sulh Ceza Mahkemesinin Ceza Kanununun mer'iyete girdiği tarihten sonra mer'iyete giren Borçlar Kanununun 57 nci maddesi gayrimenkule giren hayvanları ............ öldürmeye bir hak bahşetmiş olmasundan veasaireden dolayı vermiş olduğu beraat kararın, mezru tarlaya zarar ika etiği sırada tasarruf hakkının himayesi maksadiyle itlàf cezaî mesuliyeti istilzam etmez" diyerek tasdik etmisti : 1939 - 40 temyiz kararları : ceza kısm : Sa : 57.

(2) T. Taner : Sa: 648; Magnol : Sa: 304 .

(3) Magnol : Sa : 304 . 
lerde, muafiyet zimnen mevcut addedilir (1). Cerrahi ameliyelerle boks ve güreş gibi sporlar bu sahada zikredilebilir.

\section{Netice :}

Su halde medenî kanunun 894 üncü maddesi de kanunun müsaadesine dayanan yeni bir beraet (muafiyet) nesebi olarak kabul edilemez mi?

T. Taner buna müspet cevap vermektedir (2). Bizim kanaatımiz da bu merkezdedir. Zaten bunun aksini kabul, kanunun kendisine bahșettiği bir sâlâhiyeti, bir hakkı kullanan bir vatandașı, bir suçlu mevkiine düşürmek, memlekette de hukuk ve adalet hakkında birtakım șüphelerin doğmasına sebebiyet vermek demek olurdu.

Bütün bu sebeplerden dolayı netice olarak Türk Hukukunda mal için meşru müdafaanın kabul edildiği sonucuna varmak zorundayız.

Fakat tatbikatta bir istikrar uyandirmak ve en ufak tereddütleri izale etmek bakımindan C. K. 49/2 yi, ceza hukukundaki yeni temayüllere uygun olarak meșrû müdafaayı bütün hukuken himaye edilen menfaatlere ve haklara teșmil edecek șekilde değiștirmek belki de en çok temenni edilecek şeydir.

(1) T. Taner : $\mathrm{Sa}: 408$.

(2) $\mathrm{Sa}: 649$. 